Received: December 11, 2017

\title{
Discussion on College Students' Ideological and Political Education Ideology Construction and Values Based on Brain Neuroscience*
}

\author{
Wenqian Sun ${ }^{1}$ \\ Northeast Normal University \\ Zheng $\mathrm{Li}^{3}$ \\ Northeast Normal University
}

\author{
Fengrong Zhang ${ }^{2}$ \\ Northeast Normal University \\ Wang $\mathrm{Xi}^{4}$ \\ Jilin Academy of Social Sciences
}

\begin{abstract}
This paper takes college students' ideological and political education ideology construction and values as the research goal, and uses the methods of literature analysis, interdisciplinary research and questionnaires to study the ideology construction of ideological and political education of college students in China and the status quo of their values, it summarizes current problems of diversified ideals and beliefs and complex value orientations in college students' ideological and political education ideology construction and values. This paper analyzes the main causes of the problems, based on the survey results, it follows the laws of brain science and brain activities, makes full use of the relevant research results of cognitive science and social psychology, and explores the ideology construction of college students' ideological and political education and their values from the three aspects of the characteristics, classification and essence of ideological and political education cognition, and provides a theoretical basis for promoting the effectiveness of college students' ideological and political education construction.
\end{abstract}

\section{Keywords}

Ideological and Political Education $\bullet$ Ideology Construction $\bullet$ Values $\bullet$ Cognitive Science

\footnotetext{
* National Social Science Fund" An Empirical Study on the Advancement of Big Data Social Governance", Project number: 17BSH135

${ }^{1}$ Marxist School, Northeast Normal University, Changchun 130024, China. Email: 379028483@qq.com

${ }^{2}$ Correspondence to: Fengrong Zhang (PhD), Marxist School, Northeast Normal University, Changchun 130024, China. Email: zhangfr631@ nenu.edu.cn

${ }^{3}$ Marxist School, Northeast Normal University, Changchun 130024, China. Email: 673073670@qq.com

${ }^{4}$ Institute of economics, Jilin Academy of Social Sciences, Changchun 130033, China. Email: 2198805606@qq.com
} 
Zhang, Sun, Li, Xi / Discussion on College Students' Ideological and Political Education Ideology Construction and...

Ideological and political education is a social education activity carried out under certain historical conditions (Bell \& York, 2010). It is a fine tradition and a political advantage of our party. College students are the builders and successors of the future of our motherland, and their ideological and political education is particularly important for the future of our country. It's not only related to the overall development of individuals, but also to the overall development direction of the society (Brookes, 1995). However, under the background of globalization and the Internet, the ideological and political education of college students is being influenced by non-mainstream ideologies and various negative social phenomenon (Bajaj, 2012), and the effectiveness of ideological and political education in colleges and universities is facing a severe test. Therefore, a serious issue that college ideological and political educators must face and think about is how to target the microscopic psychological characteristics of contemporary college students, follow the laws of brain science and brain activities, and improve the effectiveness of ideological and political education for college students (Creedon \& Mai, 2005).

Through the review of relevant references at home and abroad (Söderbaum, 2004), the previous research on ideological and political education of college students mainly focused on the methods, contents, processes and carriers of the education, however, as a kind of social education activity of human idea transformation and spiritual production, the effect of ideological and political education is inseparable from people's cognitive process of ideological and political education and the cognitive effect (Park \& Kim, 2008). Cognition is the process by which the human brain processes external information. Therefore, the natural basis for the formation of cognition of college students' ideological and political education is the physical structure and function level of the human brain (Solomon \& Jr, 2011). The cognition of ideological education belongs to a relatively new research field, mainly focusing on the acceptance and internalization of ideological and political education, the study of cognitive factors, the study of moral cognition (Bong, 2001), and other aspects. The main ideas include: the study of the role of cognition of ideological and political education in the generation of ideological and political education contexts by cognitive schemas and mechanisms (Buckler \& Dolowitz, 2012), and demonstration of the role of cognition in the generation and development of ideological and political education by cognitive roots and cognitive contradictions (Armaline \& Hoover, 1989).

Based on the above analysis, this paper takes the rules of brain science and brain activities as the starting point, and uses the questionnaire survey method to investigate the ideology construction of ideological and political education and the status quo of the values of college students in China. The survey shows that the current situation of college students' ideological and political education is generally optimistic, but there are still some students who have ideology construction and value orientation problems such as ambiguity of ideals, lack of social responsibility, and distortion of value orientation. Combined with the investigation results, this paper discusses to strengthen the ideology and value construction of ideological and political education of college students from the perspectives of the characteristics, classification and essence of ideological and political education cognition, in the hopes of providing relevant theoretical basis for improving the effectiveness of ideological and political education of college students. 


\section{Investigation on college students' ideological and political education ideology construction and status quo of values}

Facing the whole country, this paper adopts the method of online questionnaire survey to investigate the ideological and political state of college students. Through statistical analysis of survey results and informal discussion with college students, it summarizes the problems existing in the ideological and political education ideology construction and values.

\section{Diversified rational beliefs}

Ideal is a kind of social consciousness of an individual's pursuit of political position, outlook on life, values, and world outlook. And belief is someone's firm conviction in the correctness of certain ideas. When pursuing an ideal, the individual will act according to its viewpoints and principles, and he/she is convinced that it can be achieved, and this kind of conviction is belief, so ideals and beliefs are interrelated.

Contradiction of political beliefs The survey results of college students show that their political beliefs are generally firm, that is, they agree with China's current system and party leadership, but the results of the survey on college students' motivation to join the party show (Figure 1) that only $27.7 \%$ of students join the party because of political beliefs, and about $60 \%$ of students join the party in order to lay the political foundation for their future development. This reflects the contradiction of the political beliefs of college students. Although they firmly believe in the leadership of the Communist Party of China, their motives for joining the party are not pure and their political consciousness is weakened. Some students even have a sense of closeness to Western values.

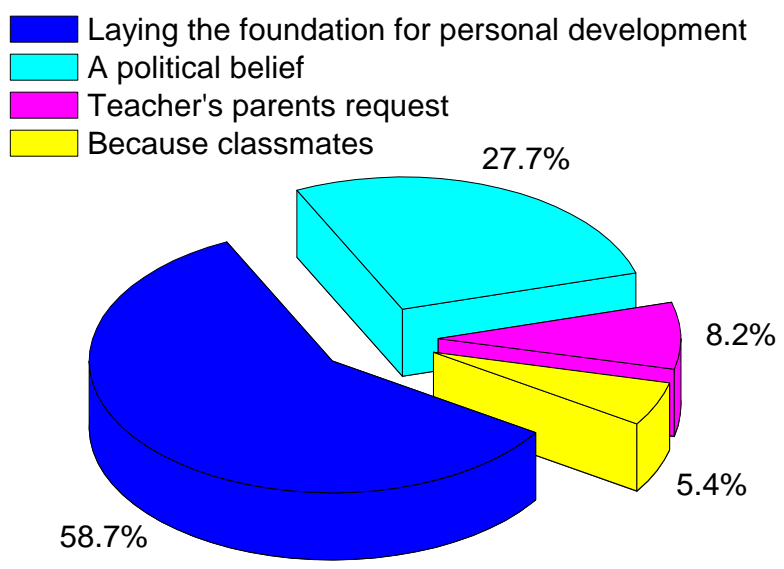

Figure 1. Investigation on students' motivation of joining the party.

Low-end ideal of life: The ideal of life is the embodiment of life outlook, values, and world outlook in life goals. The life ideals of college students are generally in a low-end state. From the survey results in Figure 2, it 
Zhang, Sun, Li, Xi / Discussion on College Students' Ideological and Political Education Ideology Construction and...

can be seen that only $4.8 \%$ of students go to college to contribute to society. Most students' life ideals are more pragmatic and far from national development and social needs. This is mainly because their cognitive level still stays in the faith of practical stage, and they have not established a belief in communism and socialism with Chinese characteristics.

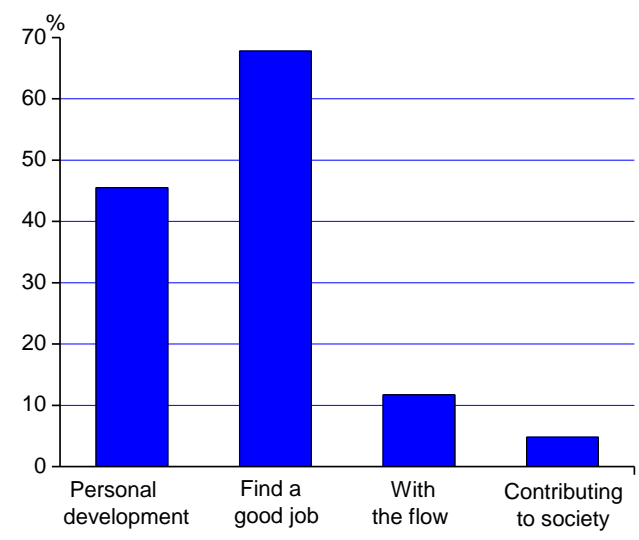

Figure 2. Purpose of going to college.

Instability of ideals and beliefs Because college students do not form the initiative and constructiveness of cognition of ideological and political education, their ideals and beliefs are highly susceptible to changes in the external environment and their own emotions, people and things they have encountered or certain social phenomena may cause a huge change in their original beliefs, which is both a difficult problem and an opportunity for ideological and political educators. Because its instability can also be considered as the plasticity of college students' ideals and beliefs, we should fully grasp their cognitive laws and make them establish firm ideals and beliefs.

\section{Complex value orientations}

Value orientation compatibility Under the background of globalization and the Internet, the value orientation of college students has received strong impacts. On the one hand, they insist on the value orientation of collectivism, and they believe in the correctness of socialist core values, on the other hand, they also believe in the acquisition of personal interests, their sense of national identity is weakened, and their ideology is affected by individualism and utilitarianism of Western ideology.

Selfhood of value orientation: The survey shows that in the evaluation criteria of life values, students who choose national and social standards are about $10 \%$ less than other criteria. As shown in Figure 3, only 10.4\% of students choose to give up personal interests when there is a conflict between personal interest and national collective interest, while $75 \%$ of students say it depends on the situation. 
Zhang, Sun, Li, Xi / Discussion on College Students' Ideological and Political Education Ideology Construction and...

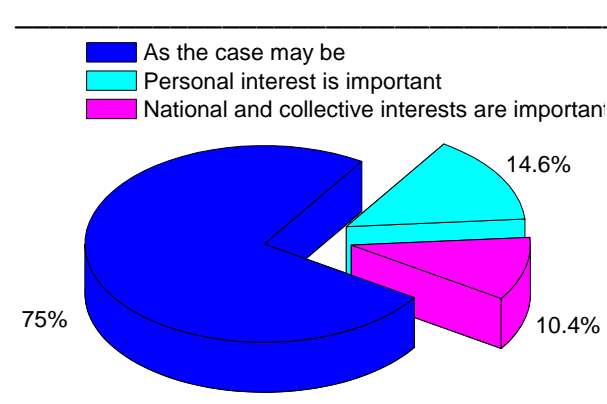

Figure 3. How to choose when conflicts arise between individual, national and collective interests.

Figure 4 shows the survey results of the question "what should life pursue most?" Most students chose material and spiritual pursuits, and only $26.4 \%$ of students chose life ideals.

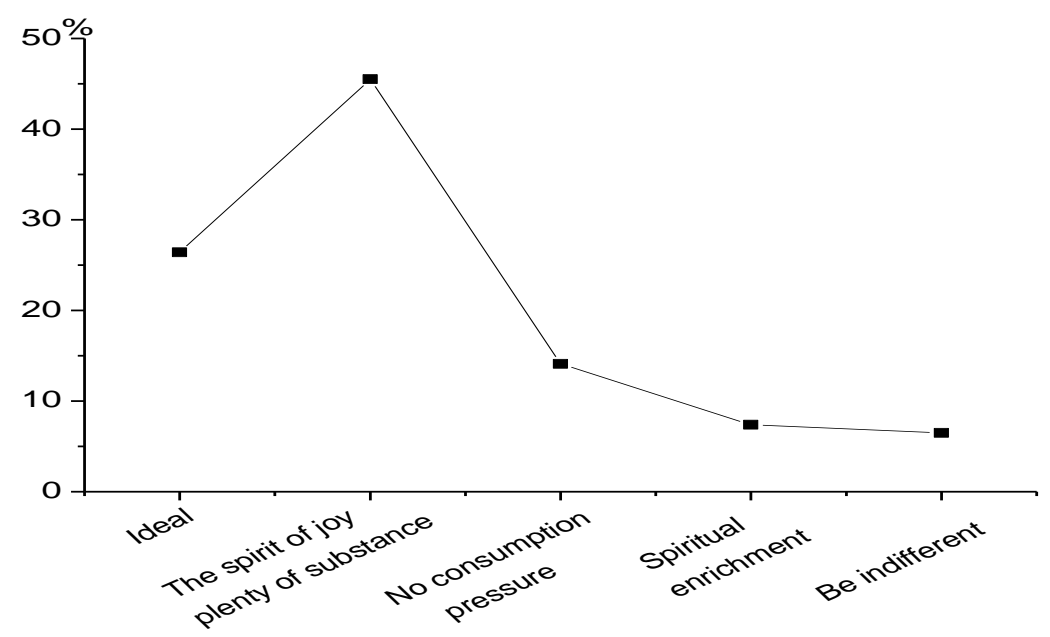

Figure 4. What should life pursue most?

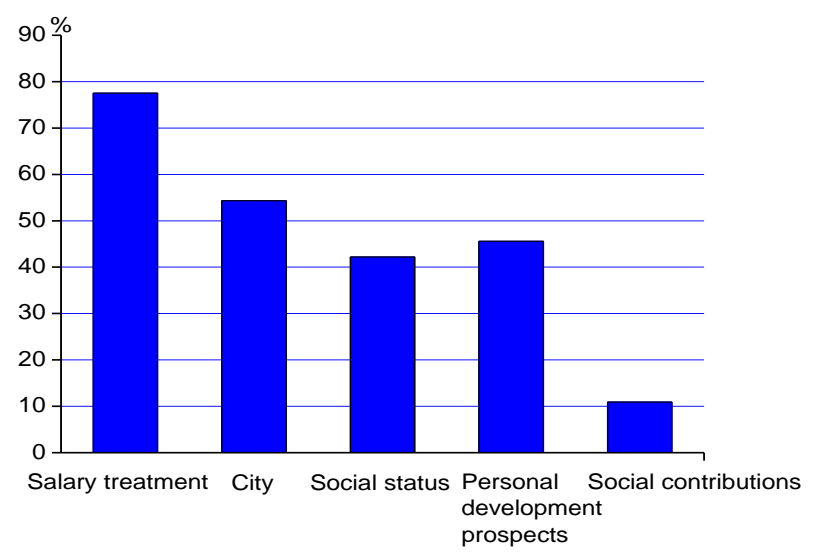

Figure 5. Selection result of the most important factor in profession. 
Utilitarianism of value orientation: As shown in Figure 5, salary, city and individual career development are the three most important factors for college students when choosing a career. Only $10.9 \%$ chose to contribute to society. From this result, it can be seen that focusing on personal interests and development is the main feature of the value orientation of college students.

It can be seen from the survey results that although the current status of ideological and political education of college students is generally optimistic, there are still some students who have ideology construction and value orientation problems such as ambiguity of ideals, lack of social responsibility, and distortion of value orientation.

\section{Discussion on ideological and political education ideology construction and values of college students from the perspective of cognition}

Cognition is the process by which the human brain processes the external information. The cognition of ideological and political education can be viewed from microscopic, mid-scopic and macroscopic levels (Dixit \& Londregan, 1998). The microscopic ideological and political education cognition is the premise and foundation for the ideological and political education, it is a process of people's receiving, understanding, processing and internalizing of information that reflects social code of conduct and values. As shown in Figure 6, the mid-scopic level emphasizes on the individual's cognitive process and cognitive outcome of value function and ideological criteria. While macroscopic ideological and political education cognition focuses on the cognitive outcome, it transcends the recognition phase of the mid-scopic level, and has reached the stage of faith. The relationship between the three can be represented by Figure 7 (Camobreco, 2016).

\section{Classification and characteristics of ideological and political education cognition}

The cognitive situation of ideological and political education is complex. In order to facilitate understanding, it is usually divided into three aspects: individual cognition and group cognition, fact cognition and value cognition, explicit cognition and implicit cognition (Jong, 2010), as shown in Figure 8.

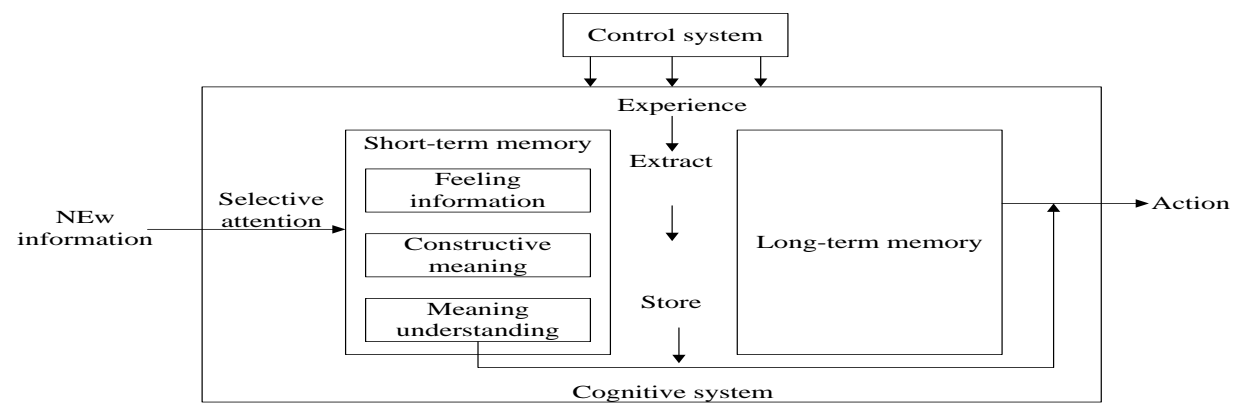

Figure 6. Ideological and political education cognitive process. 


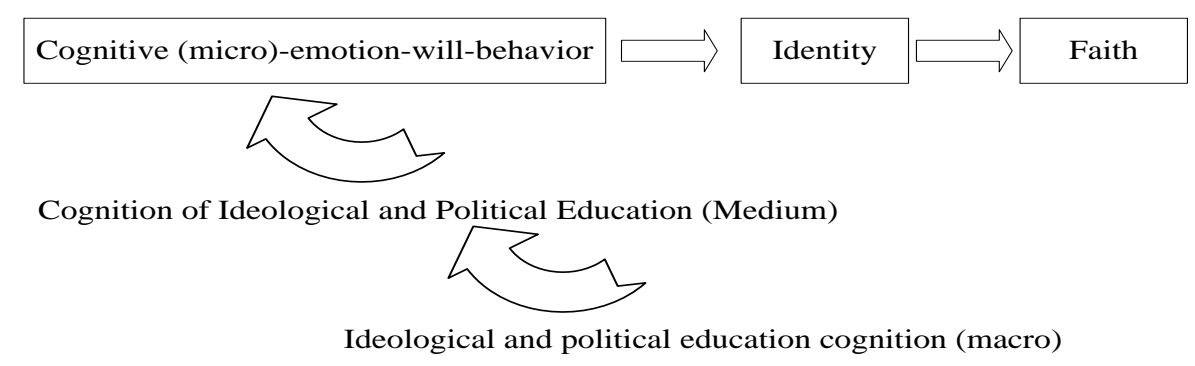

Figure 7. Definition of the cognitive concept of ideological and political education.

Based on grasping the classification of ideological and political education, ideological and political educators should also have a detailed understanding of their characteristics in order to better carry out ideological and political education for college students. Figure 9 shows the cognitive characteristics of ideological and political education summarized in this paper (Ansell \& Lindvall, 2013).

Premise and fundamentality of cognitive system: Cognition is the basis for the formation and development of subject values. Subjects need to achieve the educational goals of improving ideological cognition and individual transformation under a certain knowledge background and vision. Delivering basic ethics and mainstream values to educators is the primary task of ideological and political education, while the premise is that the subjects are fully aware of the ideological and political education.

Integrity and complexity of the cognitive system: In the cognition of ideological and political education, the understanding, emotion, will and action of the cognitive subject are a whole (Matias \& Zembylas, 2014), which involves the interaction between the subject's brain, body and social environment. In the process of cognition, the subject first forms the overall image of the object, and as the cognition deepens, it recognizes the deeper meaning of the object. Complexity is reflected in both the process of cognition and the outcome of cognition. The cognition of the subject to the object involves the continuous improvement of the cognition of the object from the perceptual level to the rational level to the level of the world view, and the subject must not only "understand and master" the ideological and political education, but also "believe and practice" it (Grose, Grabe \& Kohfeldt, 2014).

Value and ideology of cognitive content: The object of ideological and political education cognition should have a certain value orientation to the subject, which can help the subject to establish a correct outlook on life and values and form a correct political belief. Therefore, ideological and political education is the process of subjectivizing the object. Ideological function is the basic function of ideological and political education (Cochran-Smith, 2002). By instilling and educating the subject with ideologies such as moral norms, political opinions and ideas, the subject is cultivated to become a person who meets the interest of a certain class.

The unity of knowing and doing of cognitive goals: The essential attribute of ideological and political education is practical. The unity of knowing and doing is the basic principle followed by the ideological and political education. That is, the purpose of learning is not to use the theory per se to guide the practice, but to 
apply the acquired theory and ideas in guiding practice, and ultimately achieving the goal of understanding the world and transforming the world.

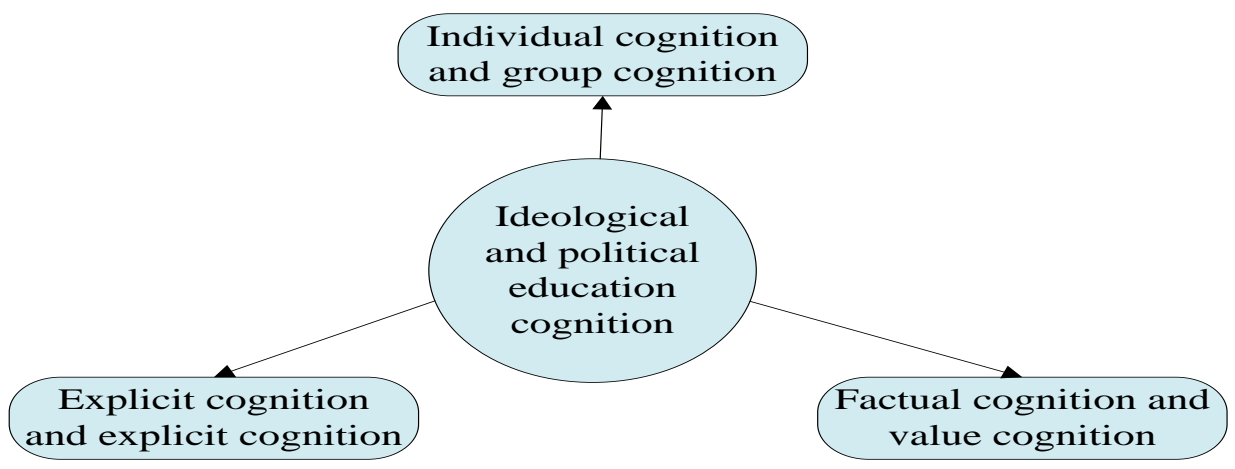

Figure 8. Cognition classification of ideological and political education.

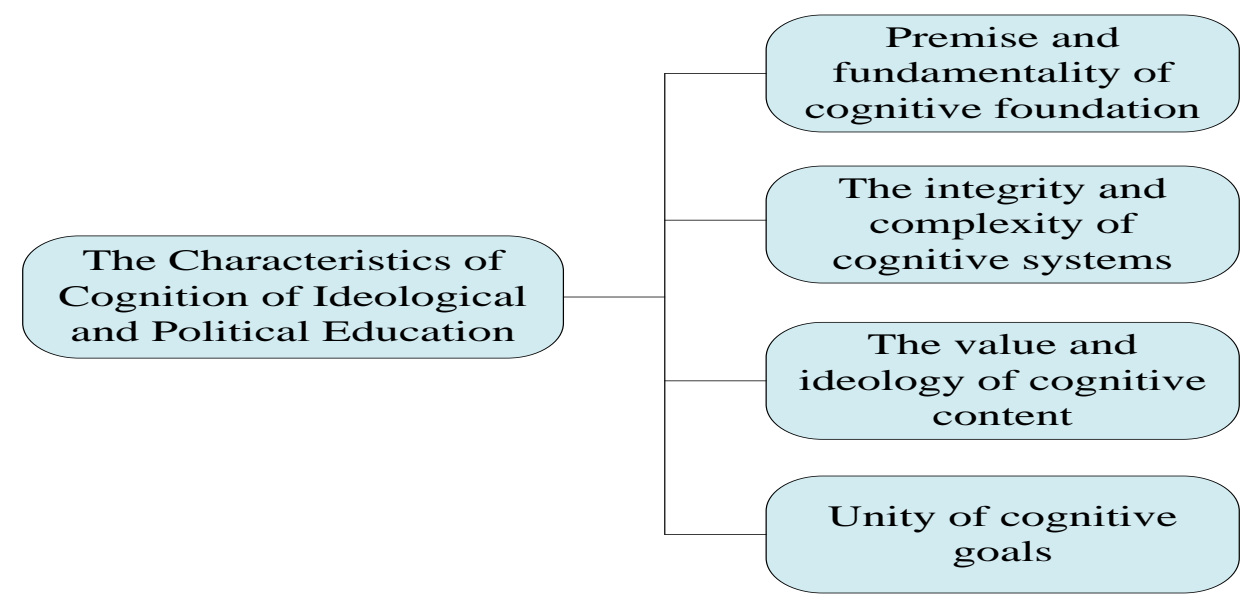

Figure 9. Characteristics of cognition of ideological and political education.

The essence of cognition of ideological and political education

It is the information processing process in which the subject transforms ideological and political education from a substance to a concept: The cognition of ideological and political education is the reflection of the human brain on the essence of objective reality. It is the process by which the cognitive subject processes the external sound, image and other information and finally transforms into a valuable connotation based on its original social experience. Therefore, in the ideological and political education, we should pay more attention to the use of auxiliary teaching methods on the basis of the original theoretical explanation. 
Zhang, Sun, Li, Xi / Discussion on College Students' Ideological and Political Education Ideology Construction and...

It is a special social cognition of the subject for political demands Individuals always live in a certain political and social environment. Their cognition of ideological and political education is formed in social life through learning and social practice activities, and the process of ideological and political education also implies the education and dissemination of political culture. And individuals have achieved their social development under the interaction of ideological and political education and society.

It is the value cognition of the subject based on certain social relations Human social production can be divided into three basic forms: human self-production, material production and spiritual production (Kevin, 1990). Ideological and political education cognition is a spiritual production practice activity that takes place in certain social relations and takes the achieving of value goals as the objective, in this process, the subject internalizes social values into their own values and manifests them through certain behaviors and practices.

\section{Conclusion}

From the perspective of brain neuroscience, this paper discusses the ideological and political education ideology construction and values of college students. The main conclusions are as follows:

By sorting out relevant references, this paper integrated ideological and political education with the brain neuroscience, and proposed to discuss the ideological and political education ideology construction and values of college students from the perspective of cognitive science.

This paper used questionnaires to investigate the ideological and political education ideology construction and the status quo of values of college students. The results showed that the current situation of college students' ideological and political education is generally optimistic, but there are still problems such as diversified rational beliefs and complicated value orientation.

According to the survey results, this paper discussed the ideological and political education ideology construction and values of college students from three aspects: the cognitive characteristics, classification and essence of ideological and political education, which provided relevant theoretical basis for promoting the ideological and political education.

\section{References}

Ansell, B., \& Lindvall, J. (2013). The political origins of primary education systems: ideology, institutions, and interdenominational conflict in an era of nation-building. American Political Science Review, 107(3), 505522. http://dx.doi. org/10.1017/s0003055413000257

Armaline, W. D., \& Hoover, R. L. (1989). Field experience as a vehicle for transformation: Ideology, education, and reflective practice. Journal of Teacher Education, 40(2), 42-48. http://dx.doi. org/10.1177/002248718904000208

Bajaj, M. (2012). Human rights education: Ideology, location, and approaches. Human Rights Quarterly, 33(2), 481-508. http://dx.doi. org/10.1353/hrq.2011.0019 
Zhang, Sun, Li, Xi / Discussion on College Students' Ideological and Political Education Ideology Construction and...

Bell, S. E., \& York, R. (2010). Community economic identity: the coal industry and ideology construction in West Virginia. Rural Sociology, 75(1), 111-143. http://dx.doi. org/10.1111/j.1549-0831.2009.00004.x

Bong, M. (2001). Role of self-efficacy and task-value in predicting college students' course performance and future enrolment intentions. Contemporary Educational Psychology, 26(4), 553-570. http://dx.doi. org/10.1006/ceps.2000.1048

Brookes, H. J. (1995). 'suit, tie and a touch of juju' - the ideological construction of Africa: A critical discourse analysis of news on Africa in the British press. Discourse \& Society, 6(4), 461-494. http://dx.doi. org/10.1177/0957926595006004002

Buckler, S., \& Dolowitz, D. (2012). Ideology matters: party competition, ideological positioning and the case of the conservative party under David Cameron. British Journal of Politics \& International Relations, 14(4), 576-594. http://dx.doi. org/10.1111/j.1467-856x.2011.00482.x

Camobreco, J. F. (2016). Ideological realignment and the primacy of symbolic ideology. American Politics Research, 44(3), 471-495. http://dx.doi. org/10.1177/1532673x15624011

Cochran-Smith, M. (2002). Teacher education, ideology, and napoleon. Journal of Teacher Education, 53(1), 3-5. http://dx.doi. org/10.1177/0022487102053001001

Creedon, P., \& Mai, A. K. (2005). Public relations and globalization: building a case for cultural competency in public relations education. Public Relations Review, 31(3), 344-354. http://dx.doi. org/10.1016/j.pubrev.2005.05.021

Dixit, A., \& Londregan, J. (1998). Ideology, tactics, and efficiency in redistributive politics. Quarterly Journal of Economics, 113(2), 497-529. http://dx.doi. org/10.1162/003355398555667

Grose, R. G., Grabe, S., \& Kohfeldt, D. (2014). Sexual education, gender ideology, and youth sexual empowerment. Journal of Sex Research, 51(7), 742-753. http://dx.doi. org/10.1080/00224499.2013.809511

Jong, T. D. (2010). Applying cognitive science to education: thinking and learning in scientific and other complex domains. Science Education, 93(6), 1147-1149. http://dx.doi. org/10.1002/sce.20354

Kevin, P. S. (1990). Ideology, education, and social structure: elementary schooling in mid-victorian England. History of Education, 19(2), 105-122. http://dx.doi. org/10.1080/0046760900190202

Matias, C. E., \& Zembylas, M. (2014). 'when saying you care is not really caring': Emotions of disgust, whiteness ideology, and teacher education. Critical Studies in Education, 55(3), 319-337. http://dx.doi. org/10.1080/17508487.2014.922489

Park, Y. S., \& Kim, B. S. (2008). Asian and European American cultural values and communication styles among Asian American and European American college students. Cultural Diversity \& Ethnic Minority Psychology, 14(1), 47. http://dx.doi. org/10.1037/1099-9809.14.1.47

Söderbaum, P. (2004). Values, ideology and politics in ecological economics. Ecological Economics, 28(2), 161-170. http://dx.doi. org/10.1016/s0921-8009(98)00139-6

Solomon, G. T., \& Jr, L. W. F. (2011). A comparative analysis of entrepreneur and college business student values. Journal of Creative Behavior, 24(4), 238-255. http://dx.doi. org/10.1002/j.21626057.1990.tb00545.x 